\title{
Emissions of polycyclic aromatic hydrocarbons (PAHs) during hydrothermally treated municipal solid waste combustion for energy generation
}

\author{
Nana Peng, Zhengang Liu*, Tingting Liu, Chao Gai \\ Research Center for Eco-Environmental Sciences, Chinese Academy of Sciences, Beijing 100085, China \\ University of Chinese Academy of Sciences, Beijing 100049, China
}

\section{H I G H L I G H T S}

- PAH emissions from H-MSW combustion and H-MSW/coal cocombustion were investigated.

- Compared to MSW, less PAHs were generated from H-MSW combustion. - Interactions occurred between $\mathrm{H}$ MSW and coal during co-combustion.

- The interactions suppressed PAHs formation and reduced the toxicity of PAHs.

\section{A R T I C L E I N F O}

\section{Article history:}

Received 7 July 2016

Received in revised form 25 September 2016

Accepted 8 October 2016

Available online 20 October 2016

\section{Keywords:}

Hydrothermal pretreatment

Co-combustion

Flue gas

Interaction

Waste biomass
G R A P H I C A L A B S T R A C T

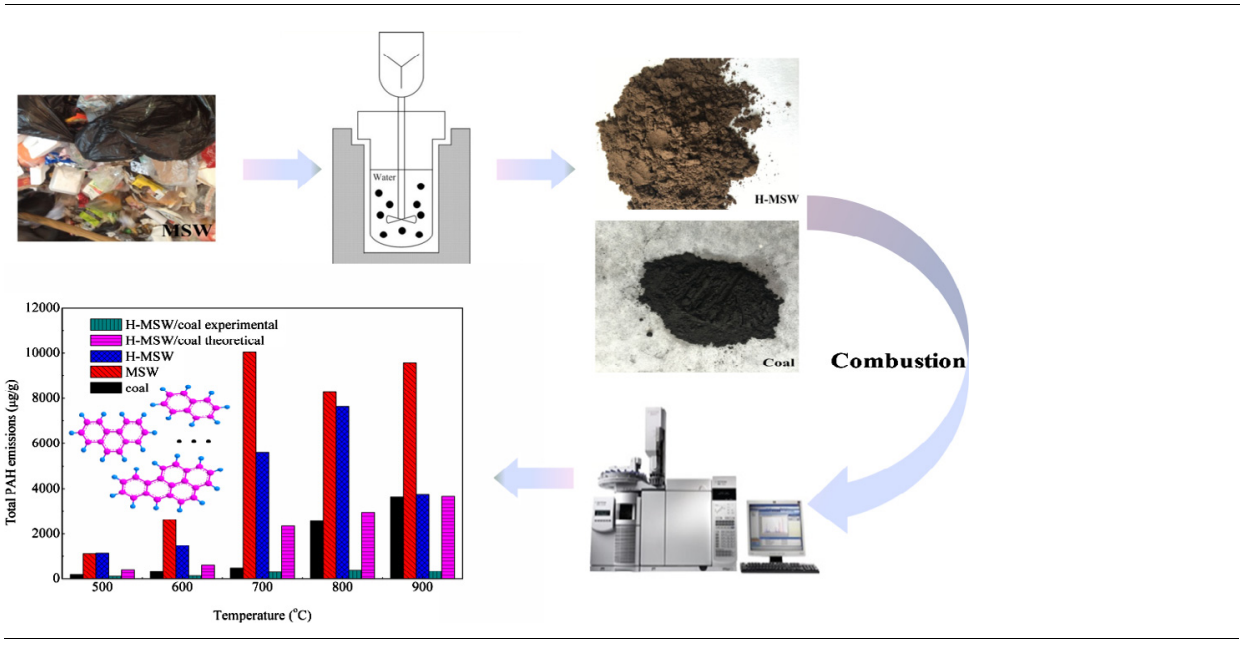

\begin{abstract}
A B S T R A C T
Hydrothermal treatment (HT) is one of the efficient approaches for upgrading municipal solid waste (MSW). In the present study, emission characteristics of polycyclic aromatic hydrocarbons (PAHs) from hydrothermally treated municipal solid waste (H-MSW) combustion alone and H-MSW/coal cocombustion were investigated at different temperatures. The results showed that for all fuel combustion, the majority of PAHs were 3- or 4-ring PAHs. In addition, flue gas had the highest yields of PAHs followed by fly ash and bottom ash, while the ring number of dominated PAHs in fly ash was higher than those in flue gas and bottom ash. Compared to MSW, H-MSW combustion generated less PAHs at the value of 1131.95-7649.24 $\mu \mathrm{g} / \mathrm{g}$. The blending of H-MSW and coal reduced total PAH emissions and positive interactions were observed between H-MSW and coal during co-combustion. The toxicity equivalent quantity (TEQ) values of the PAHs from combustion were in the order MSW > H-MSW > H-MSW/coal, which was consistent with the total PAH emissions. The present study illustrated that significant reduction of PAH emissions and toxicity from combustion could be achieved by HT and the blending of H-MSW and coal.
\end{abstract}

(c) 2016 Elsevier Ltd. All rights reserved.

\footnotetext{
* Corresponding author at: 18 Shuangqing Road, Beijing 100085, China.

E-mail address: zgliu@rcees.ac.cn (Z. Liu).
} 


\section{Introduction}

About 1.7-1.9 billion metric tons of municipal solid waste (MSW) is generated each year in the world [1]. Therefore, the disposal of municipal solid waste (MSW) is emerging to be the most urgent and important task because of the ever-increasing quantities and the harmfulness on environment and health, especially for developing countries [2-4]. The most common disposal method of MSW is landfilling in the world due to the low technical requirements [1]. However, landfill suffers from serious secondary pollution, such as pollution of air, ground water and soil. In addition, the lack of land resource also restricts the application of landfilling. Recently, MSW incineration has received considerable attention as a promising method for effective energy recovery, significant volume reduction (by up to $70 \%$ in weight and $90 \%$ in volume) and high degree detoxicity [5,6]. However, high moisture content, low calorific value and heterogeneous nature are the main drawbacks associated with the incineration of MSW and as a result, MSW combustion has low energy efficiency and relatively high pollutant emissions [7]. Therefore, pre-treatment is needed to homogenize raw MSW and improve its fuel property prior to combustion.

Hydrothermal treatment (HT), as a pre-treatment process, has been widely applied for upgrading of biomass waste, especially for high moisture content of biomass feedstock [8-10]. Compared to pyrolysis pretreatment, HT exhibits low energy consumption and high conversion efficiency owing to obviating the drying process and conducting at low temperature $[11,12]$. To date, numerous studies have been reported about HT process on upgrading of lignocellulosic biomass but limited studies are available about HT of MSW. Lu et al. investigated fuel quality and combustion behavior of hydrothermally treated MSW (H-MSW) and the results showed that HT improved fuel property of MSW, such as lowered moisture content, homogenized shapes and increased energy density [7]. Similarly, it was reported that the heating value of MSW was improved by HT through high formation of fixed carbon [13]. Apart from HT, co-combustion of MSW and coal is another effective and economical option, which can not only increase the calorific value but also buffer the impact of the variable qualities of MSW on combustion process [14]. With the increasing fuel quality of H-MSW, further improved combustion behaviors are expected during co-combustion of H-MSW and coal compared to MSW and coal co-combustion. Muthuraman et al. studied the cocombustion behavior of H-MSW and low rank coal using thermogravimetric analysis and the results showed that the blending of H-MSW and coal had improved ignition characteristics and reduced unburned carbon compared to low rank coal [15]. Additionally, nitrogen evolution during co-combustion of H-MSW and coal in a bubbling fluidized bed was investigated, indicating that $30 \%$ of $\mathrm{H}-\mathrm{MSW}$ addition lowered the formation of $\mathrm{NO}$ and $\mathrm{N}_{2} \mathrm{O}$ [16]. Similarly, lower CO emission was achieved by $20 \% \mathrm{H}-\mathrm{MSW}$ addition to coal during combustion in a lab-scale fluidized bed reactor [17].

Polycyclic aromatic hydrocarbons (PAHs), mainly emitted from the pyrolysis or incomplete combustion of fuel, is a global environmental issue due to the carcinogenicity, teratogenicity and mutagenicity [18-20]. Nowadays, the PAH emissions standards are increasingly getting strict around the world to reduce their environmental impacts. Therefore, the formation mechanisms of PAHs during coal and MSW combustion alone have been extensively studied. For instance, Shen et al. reported PAH emissions from five coals combustion and the results showed that among the examined factors, the PAH emissions were closely related to the moisture and volatile matter content of the coal [19]. The distribution of PAHs in gaseous and particulate phases from coal combustion using a coal-stove was investigated and it was found that $95 \%$ of the total PAHs were in gaseous phase [21]. In addition, PAHs in bottom ashes from MSW incinerator were analyzed and the results showed that 3- and 4-ring PAHs were dominated in all samples [22]. Zhang et al. determined PAH contents in fly ash from MSW incinerator where 3- and 4-ring PAHs were the main constituents of PAHs [23]. However, to our best knowledge, there is no systematic study on the emission, distribution and toxicity of PAHs from $\mathrm{H}-\mathrm{MSW}$ combustion alone and H-MSW/coal co-combustion.

With the increasing importance of HT, understanding emission and distribution of PAHs from H-MSW combustion is urgent for its large-scale application. Therefore, the objective of this study aimed to (1) determine the emission, distribution and toxicity of PAHs in bottom ash, fly ash and flue gas during H-MSW combustion, (2) investigate the effect of HT on PAH emissions during MSW combustion and (3) examine the effect of the blending of H-MSW and coal on PAH emissions during co-combustion. The ultimate goal of the present study was to realize the effective and clean energy recovery from MSW.

\section{Materials and methods}

\subsection{Materials}

In this study, bituminous coal was obtained from a coal mine in Inner Mongolia, China. The simulated MSW sample was chosen in the present study and its composition can be found in our previous study [24]. Briefly, MSW was comprised of food residue (64.93 wt. $\%)$, wood waste (1.48 wt.\%), paper (12.94 wt.\%), textiles (3.11 wt.\%), and PVC (15.07 wt.\%). All samples were dried in an oven at $105^{\circ} \mathrm{C}$ for $24 \mathrm{~h}$ before use.

HT of MSW was carried out in a laboratory semi-batch 2.5-L autoclave reactor. The mixture of MSW and deionizer water (1:3 mass basis) was loaded into the reactor, and the reactor was sealed and heated to $200^{\circ} \mathrm{C}$. After remaining for $30 \mathrm{~min}$, the reactor was cooled rapidly to room temperature. The mixture was separated by vacuum filtration and the solid product (H-MSW) was dried in oven at $105{ }^{\circ} \mathrm{C}$ for $24 \mathrm{~h}$. The H-MSW/coal blend was prepared using coal weight fraction of $75 \%$. The metal contents of coal and H-MSW were determined by inductively coupled plasma-optical emission spectroscopy (ICP-OES). Around $0.1 \mathrm{~g}$ of dry sample was digested in mixed acids $\left(4 \mathrm{ml} \mathrm{65 \%} \mathrm{HNO}_{3}, 4 \mathrm{ml} \mathrm{30 \%} \mathrm{H}_{2} \mathrm{O}_{2}, 2 \mathrm{ml} 70 \% \mathrm{HClO}_{4}\right.$ and $4 \mathrm{ml} 48 \% \mathrm{HF}$ ) at $170{ }^{\circ} \mathrm{C}$ for $12 \mathrm{~h}$. The digestion liquid was evaporated to near dryness and then dissolved in $1: 1 \mathrm{HNO}_{3}$ for ICP-OES analysis. The elementary analyzer (a Vario MACRO cube Elemental Analyzer) was used to determine the ultimate analysis of the samples. Proximate analysis was obtained according to standard GB/ T212-2008. Table 1 illustrates proximate analysis, ultimate analysis and metal contents of the coal and H-MSW.

\subsection{PAHs sampling and analysis}

The laboratory scale fixed-bed tubular quartz reactor (an internal diameter of $55 \mathrm{~mm}$ and a length of $1000 \mathrm{~mm}$ ) was applied for combustion experiments in this study. When the reactor was heated to the desired temperature, the fuel sample (around $1 \mathrm{~g}$ ) placed in the quartz boat was inserted into the center zone of reactor. The fuel was combusted at the desired temperature for $30 \mathrm{~min}$ with air flow rate of $500 \mathrm{ml} / \mathrm{min}$. Quartz fiber filters (QFFs) was used to collect fly ash. The PAHs in flue gas was determined by adsorption method. The adsorption apparatus were composed of a glass holder filled with XAD-2 and two bottles of dichloromethane (DCM), which were placed in ice baths. The residue in quartz boat was collected as bottom ash. After complete combustion and cooling down to room temperature, QFFs, XAD2, absorption liquid and the bottom ash were analyzed for PAHs. 
Table 1

Ultimate analysis, proximate analysis and metal contents of H-MSW and coal.

\begin{tabular}{lll}
\hline & H-MSW & Coal \\
\hline Ultimate analysis (\%, daf) & & \\
$\mathrm{C}$ & 49.19 & 66.41 \\
$\mathrm{H}$ & 6.36 & 3.84 \\
$\mathrm{~N}$ & 2.06 & 0.74 \\
$\mathrm{~S}$ & 0.33 & 0.48 \\
$\mathrm{O}^{\mathrm{a}}$ & 42.06 & 28.53 \\
Proximate analysis $(\%, \mathrm{db})$ & & \\
Volatile matter & 88.21 & 26.43 \\
Ash & 1.61 & 11.67 \\
Fixed carbon & 10.18 & 61.90 \\
$\mathrm{Metal}$ content $(\mu \mathrm{g} / \mathrm{g}, \mathrm{db})$ & & \\
$\mathrm{Na}$ & 988.05 & 1183.25 \\
$\mathrm{~K}$ & 1000.98 & 1800.95 \\
$\mathrm{Mg}$ & 265.98 & 516.00 \\
$\mathrm{Ca}$ & 4614.33 & 7168.85 \\
$\mathrm{Al}$ & 326.18 & 6897.80 \\
$\mathrm{~Pb}$ & 8.00 & 14.88 \\
\hline
\end{tabular}

a By difference.

Table 2

The 16 priority PAHs and the corresponding retention times with GC-MS.

\begin{tabular}{llllll}
\hline $\begin{array}{l}\text { Ring } \\
\text { number }\end{array}$ & Individual PAHs & Abbreviations & $\begin{array}{l}\text { Target- } \\
\text { ion }\end{array}$ & $\begin{array}{l}\text { Retention } \\
\text { time (min) }\end{array}$ & TEF \\
\hline 2 & Napthalene & Nap & 128 & 13.49 & 0.001 \\
3 & Acenaphthylene & Acy & 152 & 19.62 & 0.001 \\
& Acenapthene & Ace & 152 & 20.34 & 0.001 \\
& Fluorene & Flu & 166 & 22.36 & 0.001 \\
& Phenanthrene & Phe & 178 & 26.00 & 0.001 \\
& Anthracene & Ant & 178 & 26.30 & 0.010 \\
4 & Fluoranthene & Fla & 202 & 30.79 & 0.001 \\
& Pyrene & Pyr & 202 & 31.62 & 0.001 \\
& Benz[a]anthracene & BaA & 228 & 36.40 & 0.100 \\
& Chrysene & Chr & 228 & 36.51 & 0.010 \\
5 & Benzo[ $b$ ]fluoranthene & BbF & 252 & 40.33 & 0.100 \\
& Benzo[ $k$ ]fluoranthene & BkF & 252 & 40.40 & 0.100 \\
& Benzo[a]pyrene & BaP & 252 & 41.36 & 1.000 \\
& Dibenz[ah]anthracene & DaA & 278 & 45.01 & 1.000 \\
\multirow{2}{*}{6} & Indeno[1,2,3-c,d]pyrene & IcP & 276 & 44.87 & 0.100 \\
& Benzo[ghi]perylene & BgP & 276 & 45.71 & 0.010 \\
\hline
\end{tabular}

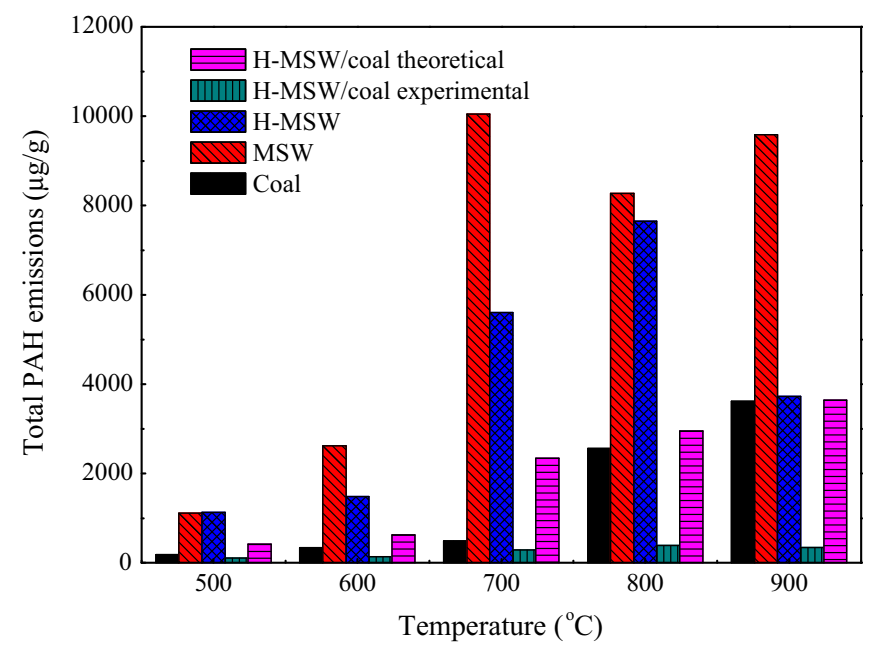

Fig. 1. Effect of combustion temperature on total PAH emissions from coal, MSW and H-MSW combustion alone and H-MSW/coal co-combustion.
The XAD-2 and absorption liquid were spiked with surrogate standard solution and then extracted in a Soxhlet extractor. The extraction was performed with DCM as the extraction solvent for $24 \mathrm{~h}$. Then the solvent DCM was replaced by hexane (about $15 \mathrm{ml}$ ) and concentrated to $1 \mathrm{ml}$ by a rotary evaporator. The concentrated extract was cleaned up using the silica column (filled with anhydrous sodium sulfate, aluminum oxide and silica gel particles from top to bottom) eluting with hexane and then a mixed solvent (n-hexane and DCM 7:3 (v/v), $70 \mathrm{ml}$ ). The mixed eluate was concentrated to nearly dryness by ultra-pure nitrogen after it was concentrated by a rotary evaporator. Subsequently, the eluate was diluted by n-hexane to $1 \mathrm{ml}$ for GC-MS analysis. The
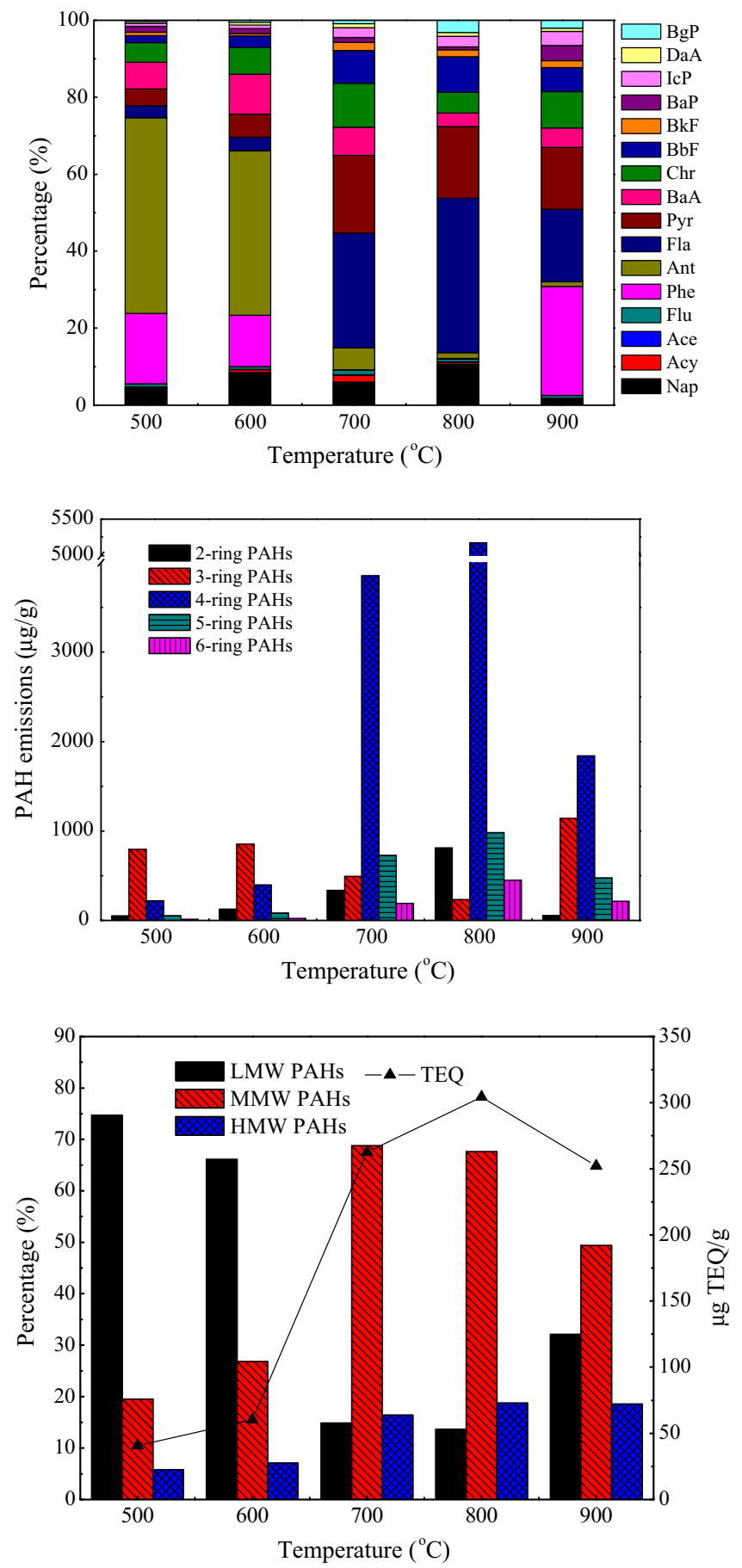

Fig. 2. The individual PAHs, ring number of the PAHs, percentages of LMW, MMW and HMW PAHs and TEQ values from H-MSW combustion. 
bottom ash and QFFs were extracted, cleaned and concentrated as the process of the XAD-2 and absorption liquid.

GC-MS (GC model Agilent 6890 and MS model 5793) equipped with a DB-5MS Agilent column ( $30 \mathrm{~m} \times 0.25 \mathrm{~mm}$ i.d., $0.25 \mu \mathrm{m}$ film thickness) was used for identification and quantification of PAHs. The injector temperature was $280^{\circ} \mathrm{C}$ and the detector temperature was $300{ }^{\circ} \mathrm{C}$. The injection volume was $1 \mu \mathrm{l}$ and the GC oven temperature was programmed from $50{ }^{\circ} \mathrm{C}$ to $300^{\circ} \mathrm{C}$ at $6{ }^{\circ} \mathrm{C} / \mathrm{min}$, with an initial hold of $2 \mathrm{~min}$ at $50^{\circ} \mathrm{C}$ and a final hold of $5 \mathrm{~min}$ at $300^{\circ} \mathrm{C}$. The 16 priority PAHs characterized by US EPA were listed in Table 2, which were identified by comparing retention time using an external standard.

All experiments were replicated at least three times to make sure that the results were reproducibility and precision. Naphthalene- $d_{8}$, perylene- $d_{12}$, acenaphthene- $d_{10}$ and phenanthrene- $d_{10}$ were added as surrogates and the recovery efficiencies were $100 \pm 28 \%$ in the present study.

\section{Results and discussion}

We have reported the PAH emissions from MSW and coal combustion within the temperature range of $500-900{ }^{\circ} \mathrm{C}$ [24]. The present study focused on the comparative evaluation of $\mathrm{PAH}$ emissions from H-MSW and MSW combustion alone, and the influence of the blending of H-MSW and coal on PAHs formation during co-combustion.

\subsection{PAH emissions during $H-M S W$ combustion}

Combustion temperature is the most important factor affecting the PAH emissions during fuel combustion. The effect of temperature on PAH emissions was investigated from H-MSW combustion and the results were shown in Fig. 1. The bell-shaped curve of total PAHs was observed during H-MSW combustion. The total PAHs were in the range of $1131.96-7649.24 \mu \mathrm{g} / \mathrm{g}$ at the examined temperature range and had peak yield at $800^{\circ} \mathrm{C}$. This emission behavior of PAHs was very similar to the emission behavior of lignite combustion [25]. The similarity indicated that HT improved fuel quality of MSW and the fuel property of H-MSW resembled lignite. This observation was in agreement with the previous reports that the biochars derived from HT of biomass feedstock have similar fuel quality with lignite $[8,9]$. PAH emissions dramatically increased with the increasing temperature from $600^{\circ} \mathrm{C}$ to $800^{\circ} \mathrm{C}$ while a significant decrease in PAH emissions occurred at $900{ }^{\circ} \mathrm{C}$. This could be ascribed to the formation and emission mechanisms of PAHs. In general, some low molecular PAHs in H-MSW are connected to H-MSW matrix by weak bonds: hydrogen bonds and Van Der Waals forces. An increase in temperature is accompanied by an increase in the breakage of weak bonds leading to the liberation of small molecular PAHs. Meanwhile, the formation enthalpies of 16 PAHs are all positive indicating that the formations of PAHs are endothermic reactions. Therefore, the increasing temperature promotes the formation of PAHs. In addition, an increase of the cyclization and condensation of free radicals with increasing temperature generates more PAHs [25]. All above formation mechanisms are favorable for the increased PAH emissions with increasing temperature. However, when the temperature was above $800{ }^{\circ} \mathrm{C}$, the structure of $\mathrm{H}-\mathrm{MSW}$ was broke and the pore structure of the H-MSW was enhanced leading to more air introduced from the H-MSW combustion. Therefore, PAH emissions decreased as a result of thermal decomposition and enhanced complete oxidation reaction of $\mathrm{H}-\mathrm{MSW}$ compared to the combustion at low temperature. In other words, the shift from PAH information reactions to decomposition reactions was the major reason for the decrease of PAHs at the temperature higher than $800{ }^{\circ} \mathrm{C}$.

Fig. 2 shows the percentages of individual PAHs from H-MSW combustion. As evidenced in Fig. 2, Ant had a maximum yield of $50.87 \%$ and $42.72 \%$ at $500{ }^{\circ} \mathrm{C}$ and $600{ }^{\circ} \mathrm{C}$, respectively, compared to $18.26 \%$ and $13.67 \%$ for Phe. Fla yields peaked at $700{ }^{\circ} \mathrm{C}$ and $800{ }^{\circ} \mathrm{C}$ at the value of $29.87 \%$ and $40.13 \%$, respectively. At temperature $900{ }^{\circ} \mathrm{C}$, Phe was the most prevalent PAH compound from $\mathrm{H}-\mathrm{MSW}$ combustion. Among the 16 individual PAHs from H-MSW combustion, 3-ring PAHs were the most dominant PAHs at low temperatures of $500{ }^{\circ} \mathrm{C}$ and $600{ }^{\circ} \mathrm{C}$, while 4-ring PAHs were the majority at temperature from $700{ }^{\circ} \mathrm{C}$ to $900{ }^{\circ} \mathrm{C}$. On the basis of the ring number, PAHs are classified as low molecular weight PAHs (LMW, 2- and 3-ring PAHs), middle molecular weight PAHs (MMW, 4-ring PAHs) and high molecular weight PAHs (HMW, 5and 6-ring PAHs). The percentages of LMW, MMW and HMW PAHs from H-MSW combustion were listed in Fig. 2. It could be seen that the percentages of LMW PAHs were about $74.69 \%$ and $66.09 \%$ of total PAHs at $500{ }^{\circ} \mathrm{C}$ and $600{ }^{\circ} \mathrm{C}$, respectively, and at temperature higher than $600{ }^{\circ} \mathrm{C}$, MMW PAHs accounted for the majority of total

Table 3

The distribution of PAHs in flue gas, fly ash and bottom ash from H-MSW combustion at different temperatures.

\begin{tabular}{|c|c|c|c|c|c|c|}
\hline \multirow[t]{2}{*}{ PAHs } & \multirow[t]{2}{*}{ Distribution } & \multicolumn{5}{|c|}{ Combustion temperature } \\
\hline & & $500{ }^{\circ} \mathrm{C}$ & $600^{\circ} \mathrm{C}$ & $700^{\circ} \mathrm{C}$ & $800^{\circ} \mathrm{C}$ & $900^{\circ} \mathrm{C}$ \\
\hline \multirow[t]{3}{*}{ 2-ring PAHs } & Flue gas $(\mu \mathrm{g} / \mathrm{g})$ & 50.59 & 124.38 & 337.95 & 792.81 & 52.91 \\
\hline & Fly ash $(\mu \mathrm{g} / \mathrm{g})$ & 0.32 & 0.79 & 0.17 & 17.61 & 0.17 \\
\hline & Bottom ash $(\mu \mathrm{g} / \mathrm{g})$ & 0.32 & 0.05 & 0.03 & 0.06 & 2.21 \\
\hline \multirow[t]{3}{*}{ 3-ring PAHs } & Flue gas $(\mu \mathrm{g} / \mathrm{g})$ & 745.71 & 834.29 & 489.11 & 225.52 & 1133.73 \\
\hline & Fly ash $(\mu \mathrm{g} / \mathrm{g})$ & 47.39 & 17.05 & 3.37 & 7.44 & 5.15 \\
\hline & Bottom ash $(\mu \mathrm{g} / \mathrm{g})$ & 1.12 & 0.79 & 0.66 & 0.89 & 0.98 \\
\hline \multirow[t]{3}{*}{ 4-ring PAHs } & Flue gas $(\mu \mathrm{g} / \mathrm{g})$ & 46.27 & 80.67 & 3759.38 & 5094.44 & 1775.11 \\
\hline & Fly ash $(\mu \mathrm{g} / \mathrm{g})$ & 174.05 & 315.40 & 94.08 & 76.73 & 64.02 \\
\hline & Bottom ash $(\mu \mathrm{g} / \mathrm{g})$ & 0.50 & 0.91 & 0.39 & 0.57 & 0.35 \\
\hline \multirow[t]{3}{*}{ 5-ring PAHs } & Flue gas $(\mu \mathrm{g} / \mathrm{g})$ & 3.54 & 6.78 & 406.89 & 587.67 & 323.57 \\
\hline & Fly ash $(\mu \mathrm{g} / \mathrm{g})$ & 48.86 & 76.08 & 319.35 & 393.69 & 151.16 \\
\hline & Bottom ash $(\mu \mathrm{g} / \mathrm{g})$ & 0.13 & 0.19 & 0.44 & 0.71 & 0.11 \\
\hline \multirow[t]{3}{*}{ 6-ring PAHs } & Flue gas $(\mu \mathrm{g} / \mathrm{g})$ & 0.84 & 2.28 & 98.63 & 191.19 & 88.32 \\
\hline & Fly ash $(\mu \mathrm{g} / \mathrm{g})$ & 12.23 & 19.05 & 92.15 & 259.73 & 126.64 \\
\hline & Bottom ash $(\mu \mathrm{g} / \mathrm{g})$ & 0.06 & 0.13 & 0.39 & 0.17 & 0.06 \\
\hline \multirow[t]{3}{*}{ Total PAHs } & Flue gas $(\mu \mathrm{g} / \mathrm{g})$ & 846.95 & 1048.40 & 5091.97 & 6891.63 & 3373.64 \\
\hline & Fly ash $(\mu \mathrm{g} / \mathrm{g})$ & 282.85 & 428.37 & 509.12 & 755.19 & 347.14 \\
\hline & Bottom ash $(\mu \mathrm{g} / \mathrm{g})$ & 2.13 & 2.07 & 1.91 & 2.41 & 3.71 \\
\hline
\end{tabular}


PAHs $\left(68.78 \%, 67.61 \%\right.$ and $49.39 \%$ at $700{ }^{\circ} \mathrm{C}, 800{ }^{\circ} \mathrm{C}$ and $900{ }^{\circ} \mathrm{C}$, respectively). The percentages of LMW PAHs decreased with an increase of temperatures in the range of $500-800{ }^{\circ} \mathrm{C}$ and then increased when the temperature was further increased to $900{ }^{\circ} \mathrm{C}$. Conversely, the MMW and HMW PAHs firstly increased and then decreased with the increasing temperature.

Besides total PAH emissions, the toxicity of PAHs is also one of key concerns. Generally, the higher ring number and molecular weight the higher toxicity of the PAHs [26]. The toxicity of PAHs from H-MSW combustion was investigated and the toxic equivalent factor (TEF) by taking BaP as a toxic benchmark was shown in Table 2. The toxicity equivalent quantity (TEQ) reflects the toxicity of PAHs and is calculated by Eq. (1):

$\mathrm{TEQ}=\sum\left(\mathrm{TEF}_{\mathrm{i}} \times\right.$ Yield $\left._{\mathrm{i}}\right)$

where i represents the individual PAH compound.

The TEQ values at different temperatures were illustrated in Fig. 2. As shown in Fig. 2, the TEQ values firstly increased with the increasing temperature to reach a maximum of $304.16 \mu \mathrm{g}$ $\mathrm{TEQ} / \mathrm{g}$ at $800^{\circ} \mathrm{C}$, and then decreased to $252.13 \mu \mathrm{g} \mathrm{TEQ} / \mathrm{g}$ at $900{ }^{\circ} \mathrm{C}$, closely following the trends of total PAH emissions. It should be pointed out that Ant, Fla and Phe accounted for the majority of 16 PAHs while Bap contributed most to TEQ values at most examined temperatures (shown in Fig. S1A).

The distribution of total PAHs in flue gas, fly ash and bottom ash is critical for modeling of future emissions and ash disposal. Therefore, the distribution of PAHs in flue gas, fly ash and bottom ash from H-MSW combustion were determined (listed in Table 3). The results showed that most PAHs generated were present in flue gas, which was at least 2 times higher than that in fly ash and more than 2 orders of magnitude than that in bottom ash, respectively. For example, the yield of PAHs in flue gas, fly ash and bottom ash was $6891.64 \mu \mathrm{g} / \mathrm{g}, 755.19 \mu \mathrm{g} / \mathrm{g}$ and $2.41 \mu \mathrm{g} / \mathrm{g}$ at $800^{\circ} \mathrm{C}$, respectively. On the basis of ring number, fly ash contained high highring PAHs compare to flue gas and bottom ash, indicating that high molecular PAHs tended to accumulate on the fly ash in comparison with flue gas and bottom ash.

As a direct comparison, PAH emissions from MSW combustion showed that the bell-shaped curve peaked at $700{ }^{\circ} \mathrm{C}$ while the coal combustion showed an "increasing slope-type" shape (total PAH yields from MSW and coal combustion alone were also shown in Fig. 1 for comparison) [24]. It was worthy to note that PAH yields from MSW combustion reached the maximum value at low temperature, followed by H-MSW and coal. According to Table 1 and the previous study, the carbon contents of fuel samples were in the order coal $>\mathrm{H}-\mathrm{MSW}>\mathrm{MSW}$ (66.41\%, 49.19\% and 42.95\%, respectively). Therefore, the trend of total PAH yields was consistent with the report by Achten and Hofman that the peak of PAH yields shifted from low temperature to high or changed from the bell-shaped curve to a increasing slope-shaped curve with the increasing carbon content and aromatization [19].

Compared to MSW, H-MSW generated low yields of PAHs at examined temperatures, except for $500{ }^{\circ} \mathrm{C}(1111.28 \mu \mathrm{g} / \mathrm{g}$ from MSW combustion and $1131.96 \mu \mathrm{g} / \mathrm{g}$ from H-MSW combustion, respectively). The results were mainly related to the decrease of plastics and metal contents in H-MSW. It was reported that metals such as $\mathrm{Na}$ and $\mathrm{Pb}$ increased the formation of PAHs during combustion [26]. When MSW was pretreated by HT, some inorganic components originated in MSW released into water, resulting in decreasing metal contents of H-MSW [27]. Therefore, the decreased metal contents in part contributed to the decreased $\mathrm{PAH}$ yields. Moreover, plastics combustion generated more PAH yields compared to other MSW components [28]. During HT, the plastic underwent degradation and the decreased plastic content was also helpful to decrease PAH yields [29].
In the case of the toxicity of PAHs, TEQ values from H-MSW combustion were lower than that from MSW combustion (60.33-304.16 $\mu \mathrm{g}$ TEQ/g for H-MSW and 62.12-1199.91 $\mu \mathrm{g}$ TEQ/g for MSW from $600^{\circ} \mathrm{C}$ to $900^{\circ} \mathrm{C}$, respectively), except at $500{ }^{\circ} \mathrm{C}$ (40.84 $\mu \mathrm{g}$ TEQ/g for H-MSW and $18.29 \mu \mathrm{g}$ TEQ/g for MSW, respectively). Based on the above analysis, significant decrease of the yields and toxicity of PAHs was achieved by HT of MSW before combustion.

\subsection{PAH emissions during $H-M S W / c o a l$ co-combustion}

As shown in Fig. 1, the yield of total PAHs generated from $\mathrm{H}-\mathrm{MSW} /$ coal co-combustion firstly increased until the temperature
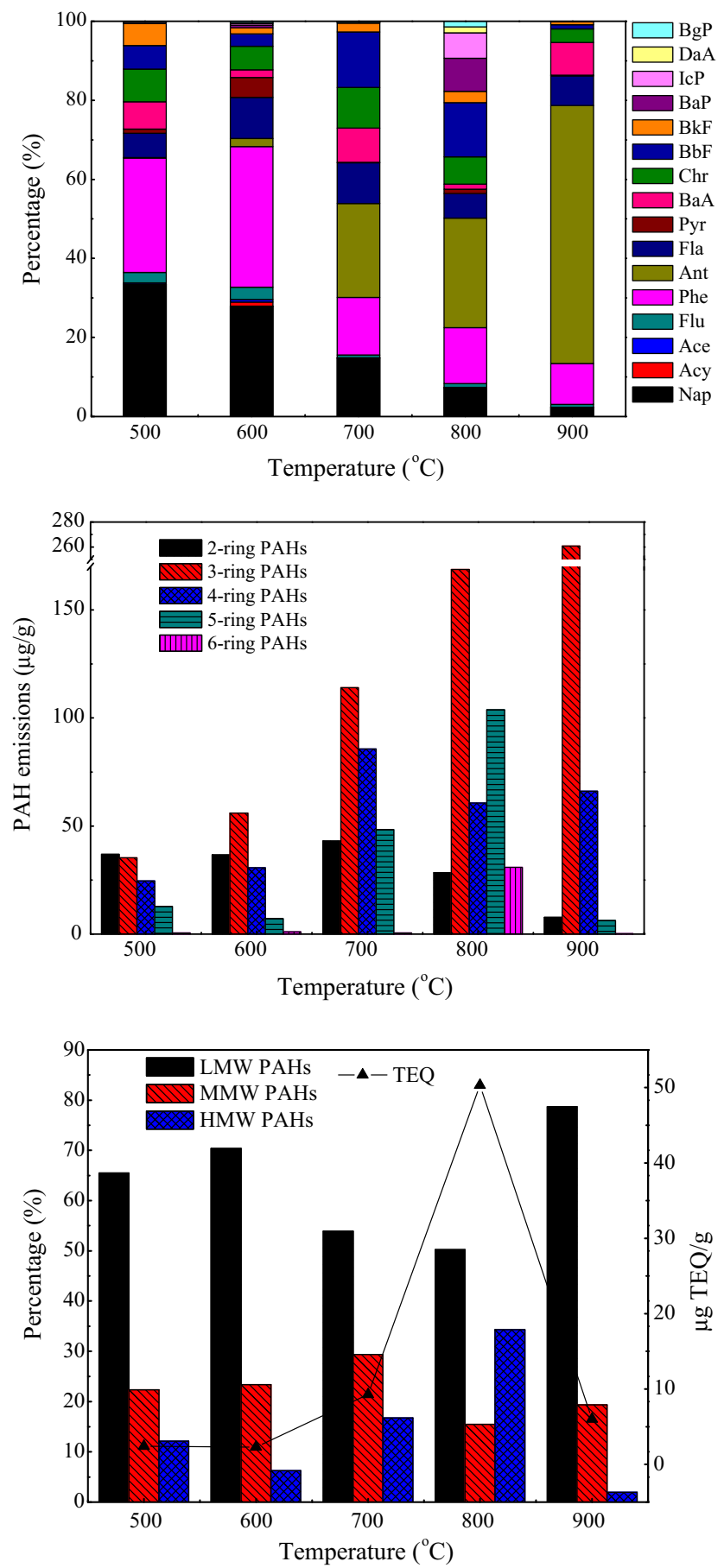

Fig. 3. The individual PAHs, ring number of the PAHs, percentages of LMW, MMW and HMW PAHs and TEQ values from H-MSW/coal co-combustion. 
reached $800{ }^{\circ} \mathrm{C}$ and then decreased with further increased temperature up to $900^{\circ} \mathrm{C}$. Compared to coal and H-MSW combustion alone, the low yields of total PAHs from H-MSW/coal co-combustion were observed at all examined temperatures, suggesting that co-combustion was an efficient way to reduce PAH emissions.

Fig. 3 presents the percentages of individual PAHs from H-MSW/coal combustion. The results showed that Nap and Phe accounted for the majority of 16 PAHs at $500{ }^{\circ} \mathrm{C}$ and $600{ }^{\circ} \mathrm{C}$. However, the yields of Ant peaked at the temperature range of $700-900{ }^{\circ} \mathrm{C}$. As shown in Fig. 3, the yield of 2-ring PAHs exhibited the maximum at $500^{\circ} \mathrm{C}$ while 3-ring PAHs were prevalent at the temperature from $600{ }^{\circ} \mathrm{C}$ to $900{ }^{\circ} \mathrm{C}$. Compared to H-MSW combustion, a shift of the dominated ring PAHs towards low ring PAHs was observed from H-MSW/coal co-combustion. On the basis of the percentages of LMW, MMW and HMW PAHs, the LMW PAHs were predominantly at examined temperatures with the range of 50.23$78.69 \%$ of total PAHs, which was higher than that from H-MSW combustion. Compared to coal combustion, the percentages of LMW PAHs from H-MSW/coal co-combustion were low and the percentages of HMW PAHs were high, except for $900{ }^{\circ} \mathrm{C}$. However, the yields of total PAHs from H-MSW/coal co-combustion were significantly lower than that from coal combustion. Therefore, lower toxicity of PAHs generated from co-combustion was expected than that from coal combustion alone.

The TEQ values were calculated to investigate the toxicity of PAHs from H-MSW/coal co-combustion (shown in Fig. 3). The TEQ values were in the range of 2.31-50.31 $\mu \mathrm{g}$ TEQ/g, which were significantly lower than that from H-MSW combustion and coal combustion alone (except for that at $700{ }^{\circ} \mathrm{C}$ ). In addition, it can be seen that although Nap, Phe and Ant were most abundant of total PAHs, BaP, BaA and BaF contributed most for TEQ values from H-MSW/coal co-combustion (shown in Fig. S1B).

The distribution of PAHs in flue gas, fly ash and bottom ash during H-MSW/coal co-combustion was shown in Table 4. The flue gas had the highest yields of PAHs, followed by fly ash and bottom ash at all examined temperatures. This trend was very similar to the trend of coal and H-MSW combustion alone. However, compared to coal and H-MSW, the PAH yields during co-combustion in flue gas, fly ash and bottom ash were remarkably decreased at most examined temperatures. When ring number was taken into account, 2-ring PAHs were most abundant in flue gas at $500{ }^{\circ} \mathrm{C}$ and 3-ring PAHs were the dominant PAHs at the temperature from
$600{ }^{\circ} \mathrm{C}$ to $900{ }^{\circ} \mathrm{C}$. As for fly ash, 4-ring PAHs accounted for the majority of total PAHs at the temperature from $500^{\circ} \mathrm{C}$ to $700{ }^{\circ} \mathrm{C}$ while 5-ring PAHs and 3-ring PAHs peaked at $800^{\circ} \mathrm{C}$ and $900^{\circ} \mathrm{C}$, respectively. In the case of bottom ash, 2-ring PAHs was dominant at $500{ }^{\circ} \mathrm{C}$ and $600{ }^{\circ} \mathrm{C}$, and the yields of 3-ring PAHs exhibited the maximum yields from $700{ }^{\circ} \mathrm{C}$ to $900{ }^{\circ} \mathrm{C}$. The above analysis showed that the ring number of dominated PAHs in fly ash were higher than those in flue gas and bottom ash from H-MSW/coal cocombustion.

\subsection{Effect of coal addition to H-MSW on PAH emissions}

Hypothetically, there was no interaction between H-MSW and coal during co-combustion and then the theoretical values of total PAH yields can be calculated by following equations:

Yield $_{\text {Blend }}=$ Yield $_{\text {Coal }} \times 0.75+$ Yield $_{\text {H-MSW }} \times 0.25$

The theoretical PAH yields were summarized in Fig. 1 and the results showed that the theoretical values of total PAHs were in the range of $418.73-3829.05 \mu \mathrm{g} / \mathrm{g}$, which were much higher than experimental values. For example, the theoretical value was $3643.84 \mu \mathrm{g} / \mathrm{g}$ at $900{ }^{\circ} \mathrm{C}$, which was 10 times higher than the experimental value $(341.35 \mu \mathrm{g} / \mathrm{g})$. As expected, the PAH yields in flue gas, fly ash and bottom ash of experimental values were all lower than those of theoretical values at examined temperatures (shown in Tables 4 and S1).

The theoretical percentages of LMW, MMW and HMW PAHs were illustrated in Table S1. Compared to theoretical values, the experimental percentages of LMW PAHs increased up to $22.94 \%$, $13.42 \%$ and $28.50 \%$ at $700{ }^{\circ} \mathrm{C}, 800{ }^{\circ} \mathrm{C}$ and $900{ }^{\circ} \mathrm{C}$, respectively. However, it was interesting to note that the percentages of HMW PAHs of experimental values were higher than that of theoretical values at temperatures range of $500-800{ }^{\circ} \mathrm{C}$ with the maximum difference of $19.33 \%$ at $800{ }^{\circ} \mathrm{C}$. While compared to theoretical value at $900{ }^{\circ} \mathrm{C}$, the decreased experimental HMW percentage indicated that high combustion temperature was helpful to reduce the formation of the highly toxic high-ring PAHs. The decreased PAHs from cocombustion were mainly ascribed to the enhanced complete combustion caused by the pore structure of H-MSW. As shown in Fig. 4, compared to smooth surface of coal, the surface of H-MSW was much rough and substantial amount of pore existed. The porous structure of H-MSW made air easily access to inner structure of

Table 4

The distribution of PAHs in flue gas, fly ash and bottom ash from H-MSW/coal co-combustion at different temperatures.

\begin{tabular}{|c|c|c|c|c|c|c|}
\hline \multirow[t]{2}{*}{ PAHs } & \multirow[t]{2}{*}{ Distribution } & \multicolumn{5}{|c|}{ Combustion temperature } \\
\hline & & $500^{\circ} \mathrm{C}$ & $600{ }^{\circ} \mathrm{C}$ & $700{ }^{\circ} \mathrm{C}$ & $800{ }^{\circ} \mathrm{C}$ & $900^{\circ} \mathrm{C}$ \\
\hline \multirow[t]{3}{*}{ 2-ring PAHs } & Flue gas $(\mu \mathrm{g} / \mathrm{g})$ & 34.71 & 33.79 & 41.45 & 27.91 & 7.63 \\
\hline & Fly ash $(\mu \mathrm{g} / \mathrm{g})$ & 0.06 & 1.13 & 1.13 & 0.51 & 0.12 \\
\hline & Bottom ash $(\mu \mathrm{g} / \mathrm{g})$ & 2.13 & 1.81 & 0.52 & 0.03 & 0.04 \\
\hline \multirow[t]{3}{*}{ 3-ring PAHs } & Flue gas $(\mu \mathrm{g} / \mathrm{g})$ & 31.93 & 51.24 & 109.25 & 165.17 & 248.79 \\
\hline & Fly ash $(\mu \mathrm{g} / \mathrm{g})$ & 1.84 & 3.40 & 3.65 & 2.93 & 11.08 \\
\hline & Bottom ash $(\mu \mathrm{g} / \mathrm{g})$ & 1.59 & 1.26 & 1.12 & 0.61 & 0.94 \\
\hline \multirow[t]{3}{*}{ 4-ring PAHs } & Flue gas $(\mu \mathrm{g} / \mathrm{g})$ & 8.31 & 24.03 & 35.47 & 30.71 & 63.62 \\
\hline & Fly ash $(\mu \mathrm{g} / \mathrm{g})$ & 16.00 & 6.12 & 49.75 & 29.49 & 1.83 \\
\hline & Bottom ash $(\mu \mathrm{g} / \mathrm{g})$ & 0.34 & 0.59 & 0.43 & 0.45 & 0.70 \\
\hline \multirow[t]{3}{*}{ 5-ring PAHs } & Flue gas $(\mu \mathrm{g} / \mathrm{g})$ & 1.52 & 4.09 & 7.92 & 5.35 & 4.83 \\
\hline & Fly ash $(\mu \mathrm{g} / \mathrm{g})$ & 11.23 & 2.88 & 39.27 & 98.31 & 1.43 \\
\hline & Bottom ash $(\mu \mathrm{g} / \mathrm{g})$ & 0.12 & 0.24 & 1.13 & 0.13 & 0.09 \\
\hline \multirow[t]{3}{*}{ 6-ring PAHs } & Flue gas $(\mu \mathrm{g} / \mathrm{g})$ & 0.26 & 0.71 & 0.11 & 0.11 & 0.13 \\
\hline & Fly ash $(\mu \mathrm{g} / \mathrm{g})$ & 0.12 & 0.23 & 0.29 & 30.68 & 0.08 \\
\hline & Bottom ash $(\mu \mathrm{g} / \mathrm{g})$ & 0.11 & 0.12 & 0.15 & 0.10 & 0.04 \\
\hline \multirow[t]{3}{*}{ Total PAHs } & Flue gas $(\mu \mathrm{g} / \mathrm{g})$ & 76.74 & 113.86 & 194.19 & 229.24 & 324.99 \\
\hline & Fly ash $(\mu \mathrm{g} / \mathrm{g})$ & 29.24 & 13.76 & 94.09 & 161.92 & 14.54 \\
\hline & Bottom ash $(\mu \mathrm{g} / \mathrm{g})$ & 4.30 & 4.03 & 3.37 & 1.32 & 1.81 \\
\hline
\end{tabular}



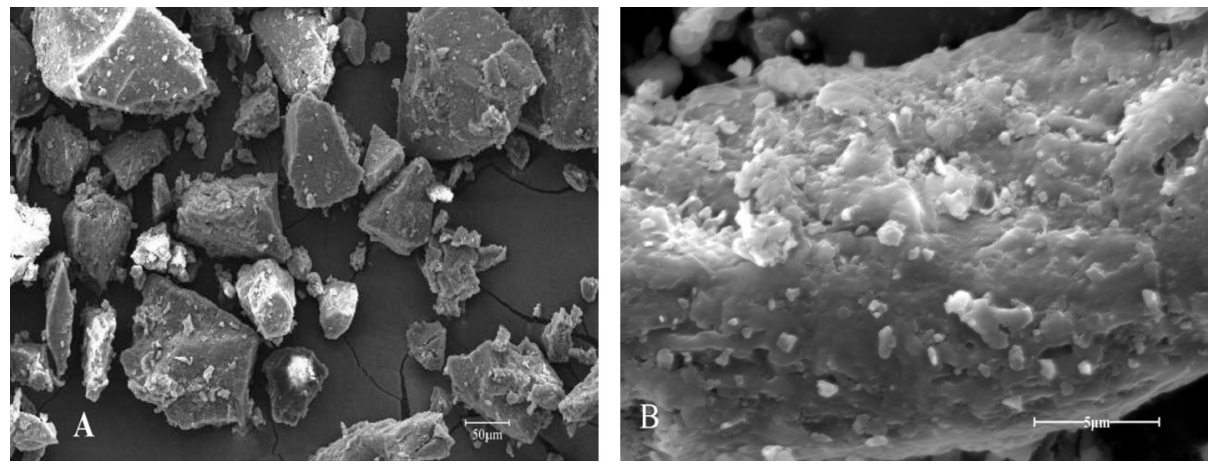

Fig. 4. The SEM images of coal (A) and H-MSW (B).

the blend during $\mathrm{H}-\mathrm{MSW} /$ coal co-combustion, and resulted in enhanced relatively complete combustion suppressing the formation of PAHs.

The theoretical TEQ values were also calculated by Eq. (1) and they were in the range of 12.96-164.99 $\mu \mathrm{g} \mathrm{TEQ} / \mathrm{g}$ (shown in Table S2). The experimental TEQ values were lower than those of theoretical values, indicating that the blending of coal and H-MSW reduced the toxicity of PAHs from respective individual combustion. The difference between theoretical and experimental PAHs suggested that the interactions between H-MSW and coal occurred during their co-combustion.
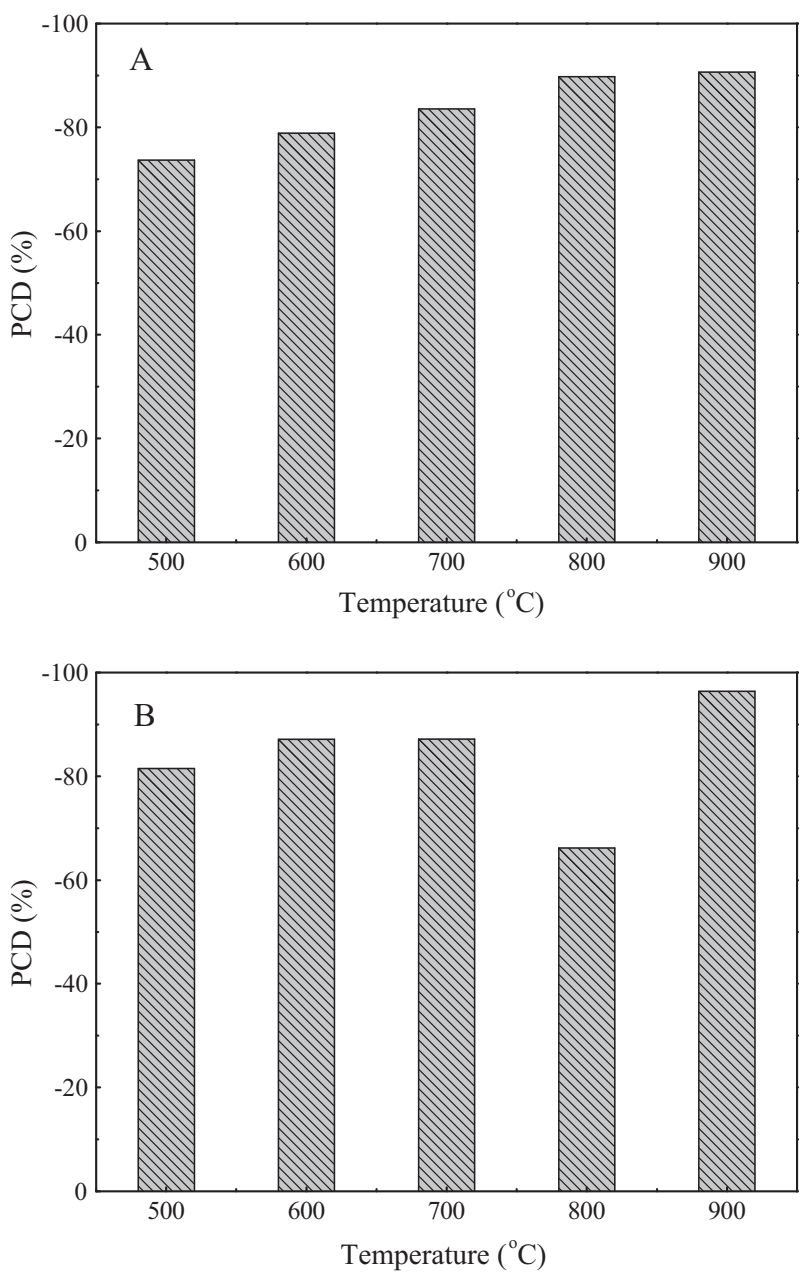

Fig. 5. The deviations between theoretical and experimental values of total PAHs (A) and TEQ values (B) from H-MSW/coal co-combustion.
In order to further compare the effect of the blending of coal and H-MSW on PAH emissions, the percent change for the difference (PCD) between experimental and theoretical PAH yields was calculated by the following equation [30]:

PCD $(\%)=\frac{\text { Experimental yield }- \text { Theoretical yield }}{\text { Theoretical yield }} \times 100$

Fig. 5 presents the PCD values of total PAHs and TEQ values from $\mathrm{H}-\mathrm{MSW} /$ coal co-combustion at different temperatures. The negative PCD values confirmed that co-combustion of coal and H-MSW decreased the yields of PAHs and reduced the toxicity of PAHs. In addition, PCD absolute values increased with the increase of temperatures from $500{ }^{\circ} \mathrm{C}$ to $900{ }^{\circ} \mathrm{C}$ (in the range of 73.66 90.63\%) implying that the higher temperatures favored the interactions between H-MSW and coal (shown in Fig. 5A). Fig. 5B illustrates that the PCD absolute values of TEQ were in the range of 66.18-96.37\%. Compared to total PAH yields, the PCD absolute values of TEQ were high, except at $800^{\circ} \mathrm{C}$ suggesting that the blending of coal and H-MSW was more efficient to reduce the toxicity of PAHs than the yields. It was worthy to note that for the toxicity of PAHs, the interaction was not proportionately to the combustion temperature, revealing the complex nature of interactions. Based on the above results, reduced total emissions and toxicity of PAHs were achieved from HT of MSW and H-MSW/coal co-combustion.

\section{Conclusions}

The generation, distribution and toxicity of 16 priority PAHs were determined from H-MSW combustion alone and H-MSW/ coal co-combustion at different temperatures. As for all samples, the 3- and 4-ring PAHs were the dominant PAHs and the most PAHs were present in the flue gas, followed by fly ash and bottom ash at most examined temperatures. Compared to MSW combustion, the total yields of PAHs from H-MSW combustion were low and the total TEQ values significantly reduced, especially at high temperatures. The total PAH emissions and the fraction of toxic high ring PAHs were further reduced by $\mathrm{H}-\mathrm{MSW} / \mathrm{coal}$ cocombustion. Significant interaction occurred between H-MSW and coal during co-combustion and the positive interactions are beneficial to decrease the yields and toxicity of the PAHs. The present study demonstrated that environmental benefits of suppressing PAHs formation and reducing PAHs toxicity can be achieved by hydrothermal carbonization of MSW prior to MSW combustion for energy generation.

\section{Acknowledgements}

The authors gratefully acknowledge financial support for Zhengang Liu from the "100 Talents" Program of the Chinese Academy of Sciences. 


\section{Appendix A. Supplementary material}

Supplementary data associated with this article can be found, in the online version, at http://dx.doi.org/10.1016/j.apenergy.2016. 10.028 .

\section{References}

[1] Chen P, Xie Q, Addy M, Zhou W, Liu Y, Wang Y, et al. Utilization of municipal solid and liquid wastes for bioenergy and bioproducts production. Bioresour Technol 2016;215:163-72.

[2] Zhou H, Meng A, Long Y, Li Q, Zhang Y. An overview of characteristics of municipal solid waste fuel in China: physical, chemical composition and heating value. Renew Sustain Energy Rev 2014;36:107-22.

[3] Zakir Hossain HM, Hasna Hossain O Uddin Monir MM, Ahmed MT. Municipa solid waste (MSW) as a source of renewable energy in Bangladesh: revisited. Renew Sustain Energy Rev 2014;39:35-41.

[4] Abila N. Managing municipal wastes for energy generation in Nigeria. Renew Sustain Energy Rev 2014:37:182-90.

[5] Assamoi B, Lawryshyn Y. The environmental comparison of landfilling vs. incineration of MSW accounting for waste diversion. Waste Manage 2012;32:1019-30.

[6] Tan ST, Hashim H, Lim JS, Ho WS, Lee CT, Yan JY. Energy and emissions benefits of renewable energy derived from municipal solid waste: analysis of a low carbon scenario in Malaysia. Appl Energy 2014;136:797-804.

[7] Lu L, Namioka T, Yoshikawa K. Effects of hydrothermal treatment on characteristics and combustion behaviors of municipal solid wastes. Appl Energy 2011;88:3659-64.

[8] Liu Z, Quek A, Hoekman KS, Balasubramanian R. Production of solid biochar fuel from waste biomass by hydrothermal carbonization. Fuel 2013;103:943-9.

[9] Liu Z, Balasubramanian R. Upgrading of waste biomass by hydrothermal carbonization (HTC) and low temperature pyrolysis (LTP): A comparative evaluation. Appl Energy 2014;114:857-64.

[10] Zhao P, Shen Y, Ge S, Chen Z, Yoshikawa K. Clean solid biofuel production from high moisture content waste biomass employing hydrothermal treatment. Appl Energy 2014;131:345-67.

[11] Berge ND, Ro KS, Mao J, Florajoseph RV, Chappell MA, Bae S. Hydrothermal carbonization of municipal waste streams. Environ Sci Techno 2011;145:5696-703.

[12] Gai C, Li Y, Peng N, Fan A, Liu Z. Co-liquefaction of microalgae and lignocellulosic biomass in subcritical water. Bioresour Technol 2015:185:240-5.

[13] In-Hee H, Hiroya A, Toshihiko M, Tatsuhiro N, Takayuki M. Recovery of solid fuel from municipal solid waste by hydrothermal treatment using subcritical water. Waste Manage 2012;32:410-6.

[14] Prawisudha P, Namioka T, Yoshikawa K. Coal alternative fuel production from municipal solid wastes employing hydrothermal treatment. Appl Energy 2012;90:298-304.
[15] Muthuraman M, Namioka T, Yoshikawa K. A comparison of co-combustion characteristics of coal with wood and hydrothermally treated municipal solid waste. Bioresour Technol 2010;101:2477-82.

[16] Lu L, Jin Y, Liu H, Ma X, Yoshikawa K. Nitrogen evolution during the cocombustion of hydrothermally treated municipal solid waste and coal in a bubbling fluidized bed. Waste Manage 2014;34:79-85.

[17] Jin Y, Lu L, Ma X, Liu H, Chi Y, Yoshikawa K. Effects of blending hydrothermally treated municipal solid waste with coal on co-combustion characteristics in a lab-scale fluidized bed reactor. Appl Energy 2013;102:563-70.

[18] Liu Z, Quek A, Parshetti G, Jain A, Srinivasan MP, Hoekman SK, et al. A study of nitrogen conversion and polycyclic aromatic hydrocarbon (PAH) emissions during hydrochar-lignite co-pyrolysis. Appl Energy 2013;108:74-81.

[19] Shen G, Wang W, Yang Y, Zhu C, Min Y, Xue M, et al. Emission factors and particulate matter size distribution of polycyclic aromatic hydrocarbons from residential coal combustions in rural Northern China. Atmos Environ 2010:44:5237-43.

[20] Perera FP, Tang D, Wang S, Vishnevetsky J, Zhang B, Diaz D, et al. Prenatal polycyclic aromatic hydrocarbon (PAH) exposure and child behavior at age 67 years. Environ Health Perspect 2012;120:921-6.

[21] Geng C, Chen J, Yang X, Ren L, Yin B, Liu X, et al. Emission factors of polycyclic aromatic hydrocarbons from domestic coal combustion in China. J Environ Sci 2014;26:160-6.

[22] Shen C, Tang X, Yao J, Shi D, Fang J, Khan MI, et al. Levels and patterns of polycyclic aromatic hydrocarbons and polychlorinated biphenyls in municipal waste incinerator bottom ash in Zhejiang province, China. J Hazard Mater 2010;179:197-202.

[23] Zhang L, Su X, Zhang Z, Liu S, Xiao Y, Sun M, et al. Characterization of fly ash from a circulating fluidized bed incinerator of municipal solid waste. Environ Sci Pollut Res 2014;21:12767-79.

[24] Peng N, Li Y, Liu Z, Liu T, Gai C. Emission, distribution and toxicity of polycyclic aromatic hydrocarbons (PAHs) during municipal solid waste (MSW) and coal co-combustion. Sci Total Environ 2016;565:1201-7.

[25] Liu S, Wang C, Zhang S, Liang J, Chen F, Zhao K. Formation and distribution of polycyclic aromatic hydrocarbons (PAHs) derived from coal seam combustion: a case study of the Ulanqab lignite from Inner Mongolia, northern China. Int J Coal Geol 2012;90-91:126-34.

[26] Chen Y, Zhao R, Xue J, Li J. Generation and distribution of PAHs in the process of medical waste incineration. Waste Manage 2013;33:1165-73.

[27] Smith AM, Singh S, Ross AB. Fate of inorganic material during hydrothermal carbonisation of biomass: influence of feedstock on combustion behaviour of hydrochar. Fuel 2016;169:135-45.

[28] Zhou H, Wu CF, Onwudili JA, Meng A, Zhang Y, Williams PT. Effect of interactions of PVC and biomass components on the formation of polycyclic aromatic hydrocarbons (PAH) during fast co-pyrolysis. RSC Adv 2015;5:11371-7.

[29] Poerschmann J, Weiner B, Woszidlo S, Koehler R, Kopinke FD. Hydrothermal carbonization of poly(vinyl chloride). Chemosphere 2015;119:682-9.

[30] Liu Z, Balasubramanian R. A comparison of thermal behaviors of raw biomass, pyrolytic biochar and their blends with lignite. Bioresour Technol 2013;146:371-8. 